\title{
Recenzja
}

\section{Prawa człowieka. Współczesne zjawiska, wyzwania, zagrożenia, red. Anna Kalisz, t. 1, Oficyna Wydawnicza „Humanitas”, Sosnowiec 2015, ss. 296}

Praca o powyższym tytule stanowi pierwszy tom serii „Prawa człowieka”. Został on wydany pod redakcją Anny Kalisz i zawiera zbiór artykułów 29 autorów, głównie polskich badaczy i znawców problematyki. Tom pierwszy został poświęcony „współczesnym zjawiskom, wyzwaniom i zagrożeniom” związanym z przestrzeganiem praw człowieka na świecie. Publikacja obejmuje zbiór wystąpień prelegentów, zaprezentowanych podczas konferencji o tym samym tytule, która odbyła się na Wyższej Szkole Humanitas w Sosnowcu w dniu 25 kwietnia 2014 r. Przy jej organizacji swój patronat - obok władz uczelni - zadeklarowały również takie instytucje, jak Sekretarz Komisji Nauk Prawnych i Ekonomicznych Polskiej Akademii Nauk (dr Bolesław Ćwiertniak) oraz Pełnomocnik Terenowy Rzecznika Praw Obywatelskich w Katowicach (dr Aleksandra Wentkowska). Do udziału w konferencji zaproszeni zostali nie tylko wybitni specjaliści z zakresu problematyki, ale również doktoranci i studenci.

Wśród autorów tomu znajdziemy więc specjalistów w dziedzinie teorii praw człowieka oraz początkujących adeptów tej sztuki. Swoje opracowania zagadnieniu poświęcili więc Artur Biłgorajski, Andrzej Bisztyga, Maciej Borski, Paweł Chmielnicki, Agnieszka Chmielowiec, Katarzyna Cichos, Tomasz Ćwiertak, Justyna Dzierżawska, Urszula Dziki, Magdalena Gurdek, Renata Jankowska, Anna Kalisz, Kamila Kasperska-Kurzawa, Katarzyna Krzywińska, Piotr Mączyński, Michalina Nawrot, Bogdan Nowosad, Jerzy 
Paśnik, Renata Płaszowska, Andrzej Pogłódek, Magdalena Półtorak, Bogusław Przywora, Katarzyna Roszewska, Bartłomiej Samek, Jarosław Sozański, Paulina Stawicka, Jurij Vasiv, Karolina Wenecka, Daniel Wojtczak.

Autorem wprowadzenia jest dr hab. Andrzej Bisztyga, profesor Uniwersytetu Zielonogórskiego. Podkreślił on szerokie spektrum badawcze zaprezentowanego materiału. Już w słowie wstępnym postawił kardynalne pytanie: „czy prawa człowieka stanowią odrębną dziedzinę prawa, czy może tak jednak nie jest?". Widzimy bowiem, iż pojęcie to funkcjonuje zarówno w świadomości społecznej oraz rozwija się jako doktryna praw człowieka, a na wielu uczelniach wyższych funkcjonują katedry praw człowieka. Jednak stanowiąc odrębny przedmiot nauczania wkomponowany w ogólny system dydaktyki uniwersyteckiej, ,prawa człowieka nie są odrębną dyscypliną prawa”. „Zagadnienia praw człowieka bardziej przenikają różne dyscypliny prawa [...], mają swój międzynarodowy i ponadnarodowy [...] wymiar konstytucyjny - zasadniczo wertykalny [...]. Ponadto prawa człowieka cechuje dynamika przejawiająca się we wkraczaniu przez nie na inne obszary, [...] na przykład prawa człowieka postępują za rozwojem stosunków społecznych, rozwojem techniki czy technologii”. Według autora tych słów zagadnienie praw człowieka nosi więc w sobie charakter wybitnie interdyscyplinarny.

Praca podzielona została na trzy działy. Są to: Prawa człowieka w ujęciu klasycznym (generacja praw człowieka), Prawa człowieka w aspekcie międzynarodowym oraz Prawa człowieka w ujęciu prawa publicznego. W kolejnym, drugim tomie planowana jest edycja materiałów przy podziale na takie zagadnienia, jak: Prawa człowieka w ramach uregulowań prywatno-prawnych oraz Prawa człowieka w świetle prawa pracy.

Po analizie opublikowanego materiału wydaje się, iż w tomie pierwszym na większą uwagę zasługują zwłaszcza artykuły Anny Kalisz, Tomasza Ćwiertaka, Pawła Chmielnickiego, Urszuli Dziki, Katarzyny Roszewskiej, Jarosława Sozańsiego, Kamili Kasperskiej-Kurzawy, Andrzeja Pogłódka i Bogusława Przywory, a także Daniela Wojtczaka i Michaliny Nawrot. W takiej też kolejności postaramy się dokonać omówienia ich wkładu w Prawa człowieka...

Przyczynek Anny Kalisz (Wyższa Szkoła Humanitas), zatytułowany Prawa kolektywne na tle klasycznego ujęcia praw człowieka, jest w istocie wprowadzeniem do tematyki związanej z prawami kolektywnymi. Autorka omówiła w referacie genezę i historię praw człowieka w kulturach greckiej, rzymskiej 
i świata judeochrześcijańskiego, ich początek upatrując w aspekcie filozoficznym i normatywnym. Usystematyzowała też płaszczyzny ochrony różnych formuł praw człowieka. Tutaj przytoczyła trzy poziomy, na jakich opiera się ochrona praw człowieka, mianowicie poziom globalny - „ochrona powszechna i uniwersalna", regionalny i krajowy. Ma z tego wynikać fakt, iż formalnie prawa człowieka stanowią dziedzinę prawa konstytucyjnego, jak i międzynarodowego. Dopełnieniem tych rozważań jest opis „generacji praw człowieka” według K. Vasaka, który to podział istnieje od 1979 r. Pierwsza generacja dotyczy wolności i praw osobistych i politycznych, i wynikała z koncepcji liberalnych, druga generacja miała powstać na podstawie potrzeb generowanych przez powstające prawa socjalne, ekonomiczne i kulturalne, a trzecia generacja praw człowieka jest pochodną idei „solidarystycznych”.

Tomasz Ćwiertniak (Akademia Ignatianum w Krakowie) w swoim artykule Zagadnienie obiektywności i uniwersalności praw człowieka. Zarys problematyki, zaprezentował zagadnienia dotyczące obowiązywania praw człowieka w sensie obiektywnym. Duża część pracy została poświęcona również ich uniwersalnemu charakterowi. Całość poprzedza wstęp odnoszący się do historycznego rozwoju konceptu praw człowieka od pierwszych sformułowań problemu przez Platona, Arystotelesa, Senekę, Marka Aureliusza, po uchwalenie w 1948 r. przez Zgromadzenie Ogólne ONZ Powszechnej Deklaracji Praw Człowieka. W poszczególnych częściach autor omówił podział pomiędzy pozytywistycznym sposobem rozumienia praw człowieka a prawem naturalnym. Szczególny nacisk położył na fakt, iż prawa człowieka nie muszą być uzasadniane. Są to bowiem prawa naturalne i takiego uzasadnienia nie wymagają. T. Ćwiertniak omówił też kwestię obiektywnej podstawy praw człowieka oraz różnice w pojmowaniu praw człowieka w światach różnych kultur i o różnym poziomie rozwoju cywilizacyjnego.

Kolejnym artykułem, o jakim chcielibyśmy nadmienić, jest praca $C z y$ istnieje publiczne prawo podmiotowe do bogacenia się? autorstwa Pawła Chmielnickiego (Wyższa Szkoła Informatyki i Zarządzania w Rzeszowie). Podjęto się w nim dokonania odpowiedzi na dość niełatwe pytanie, właśnie o „podmiotowe prawo do bogacenia się”. Analizę tego problemu autor połączył z ogólnym mechanizmem, jaki wynika z samej istoty koncepcji „praw do...”, mających przede wszystkim na celu zapewnienie ochrony jednostkom przez zbiorowości, w których żyją. 
Urszula Dziki (Wyższa Szkoła Humanitas w Sosnowcu) jest autorką artykułu Prawo człowieka do środowiska naturalnego - wybrane aspekty prawne i pozaprawne. Zajęła się w nim problemem prawa względem ochrony środowiska naturalnego $i$,prawa człowieka do życia i korzystania $z$ dobrej jakości środowiska naturalnego". W artykule wyszczególniono takie elementy problemu, jak „prawo człowieka do środowiska naturalnego w wybranych regulacjach prawnych". W ramach poszczególnych zagadnień wybrana została: 1. Problematyka prawa do środowiska naturalnego $\mathrm{w}$ prawie międzynarodowym, 2. Prawo do środowiska naturalnego w europejskim systemie ochrony praw człowieka - Europejska Konwencja Praw Człowieka, 3. Prawo człowieka do środowiska w Karcie Praw Podstawowych Unii Europejskiej, 4. Uprawnienia proceduralne związane z ochroną środowiska w Konwencji z Aarhus, 5. Prawo do korzystania ze środowiska naturalnego w konstytucjach krajowych, 6. Ochrona środowiska i prawo człowieka do środowiska w Konstytucji RP, 7. Korzystanie z walorów środowiska naturalnego jako dobro osobiste chronione przepisami Kodeksu cywilnego.

Kolejnym problemem artykułu pozostaje omówienie „pozaprawnych aspektów praw człowieka do środowiska naturalnego: 1 . Społeczny wymiar ochrony środowiska i prawa człowieka do środowiska naturalnego, 2. Filozoficzne podstawy praw człowieka do środowiska naturalnego, 3. Religijne podstawy prawa człowieka do środowiska naturalnego, 4. Kulturowe aspekty ochrony środowiska i prawa człowieka do środowiska naturalnego.

W kolejnym z omawianych artykułów Katarzyna Roszewska (Uniwersytet Kardynała Stefana Wyszyńskiego w Warszawie) zajęła się problematyką „procesu wdrażania Konwencji o prawach osób niepełnosprawnych”. Jest to interesująca próba analizy praw osób niepełnosprawnych jako części składowej praw człowieka w ogóle. Konwencja o prawach osób niepełnosprawnych jest bowiem szczególnie ważnym uzupełnieniem całości zbioru praw człowieka. Konwencja jest nie tylko deklaracją, ale zawiera szczegółowe informacje dotyczące monitoringu tak na poziomie krajowym, jak i międzynarodowym. Ważnym elementem tegoż jest stałe składanie raportów na temat postępów wykonywania postanowień Konwencji. Na tym polu złożone w 2013 r. sprawozdanie rządu polskiego do dnia dzisiejszego pozostaje niepełne. Brak w nim zwłaszcza informacji na temat praktycznego stosowania 
zasad Konwencji. Minusem sprawozdania jest też brak wyrobionej i zrozumiałej praktyki efektywności przestrzeganych przepisów.

Jarosław Sozański (Akademia Finansów i Biznesu i Wyższa Szkoła Przedsiębiorczości w Warszawie) jest autorem artykułu Kłopoty $z$ wdrożeniem traktatowych unormowań ochrony praw człowieka $w$ porzadku prawnym Unii Europejskiej. Artykuł został podzielony na części: 1. Wprowadzenie do wartości, na której zbudowana jest Unia, 2. Przybliżenie doktrynalne istoty, na których zbudowana jest Unia, 3. Pozaunijne źródła regulacji praw podmiotowych (konflikt norm EKCP i acquis a odpowiedzialność państw za skutki prawa Unii, Wybrane problemy przystąpienia Unii do EKPC, Ochrona praw podmiotowych w prawie UE na podstawie norm pozaunijnych), 4. Ochrona pozasądowa praw człowieka.

Autor odnosi się w artykule do kwestii ujednolicenia praw człowieka w krajach należących do Unii Europejskiej na bazie traktatu lizbońskiego. Tzw. „nowa kategoria wartości Unii i państw członkowskich” wynika z faktu przystąpienia Unii Europejskiej do Europejskiej Konwencji Praw Człowieka. Ponieważ państwa wchodzące w skład Unii Europejskiej i ich wypełnianie norm związanych z pełnym respektowaniem praw człowieka są oceniane przez odpowiednie organy międzynarodowe jako niewypełniające większości postulatów ich dotyczących, autor starał się odpowiedzieć na pytania o możliwość przyspieszenia i sposobów wprowadzania norm traktatowych z pełnym wypełnieniem porządku prawnego Unii Europejskiej, przy respektowaniu porządków krajowych i traktatów założycielskich. Autor zwraca uwagę na kwestie ochrony sądowej i pozasądowej obywateli Unii Europejskiej.

Kolejnym szczególnie wartym omówienia materiałem jest z pewnością zaprezentowany przez Kamilę Kasperską-Kurzawę (Uniwersytet Opolski) tekst pt. Aneksja Krymu - naruszenie pacta sunt servanda a klauzula rebus sic stantibis. W artykule autorka stara się odpowiedzieć na postawione w tytule pytanie, czy aneksja Krymu naruszyła zasadę obowiązku dotrzymywania umów międzynarodowych, czy w omawianym przypadku Rosja była uprawniona do kierowania się zasadą rebus sic stantibus. W tym celu autorka dokonała analizy sytuacji etnicznej, politycznej i krótkiego rysu historycznego. Taki zabieg miał w swoim założeniu przybliżyć perspektywy postrzegania konfliktu przez stronę ukraińską i rosyjską. W efekcie wyprowadzony został wniosek o bezpodstawności roszczeń rosyjskich i naruszenia nie tylko 
obu wspomnianych zasad (i ich możliwości interpretacyjnych), ale również podstawowej zasady proporcjonalności, a wszelkie podstawy prawne - dla których miała miejsce aneksja Krymu - pozostawać mają bez uzasadnienia. Artykuł został podzielony na następujące części: 1. Rys historyczny Półwyspu Krymskiego, 2. Faktyczne polityczne intencje przekazania Krymu Ukrainie przez Nikitę Chruszczowa, 3. Znaczenie pacta sunt servanda w konflikcie Rosja-Ukraina w kontekście klauzuli rebus sic stantibus.

Sąd Konstytucyjny w Mołdawii, to wspólny artykuł Andrzeja Pogłódka (Uniwersytet Kardynała Stefana Wyszyńskiego w Warszawie) i Bogusława Przywory (Uniwersytet Jagielloński). Opiera się on na schemacie: 1. Rys historyczny, 2. Status prawny Sądu Konstytucyjnego, 3. Zasady wyboru sędziów Sądu Konstytucyjnego i przewodniczącego, 4. Zadania przewodniczącego Sądu Konstytucyjnego, 5. Kadencyjność organu, 6. Status sędziego Sądu Konstytucyjnego, 7. Wykonywanie jurysdykcji, 8. Specjaliści i personel administracyjny Sądu Konstytucyjnego.

Przedmiotem badań Andrzeja Pogłódka i Bogusława Przywory jest funkcjonowanie Sądu Konstytucyjnego Republiki Mołdawii i analiza roli, jaką odgrywa w procesie transformacji państwa. W pracy zawarto „rys historyczny rozwoju sądownictwa konstytucyjnego na ziemiach obecnej Mołdawii od okresu międzywojennego do ogłoszenia niepodległości”. Autor wykazał, iż status prawny ww. sądu jest typowy dla sądów konstytucyjnych Europy Środkowej.

Ostatnią z pozycji, którą można wyróżnić w omawianym tomie, jest z pewnością praca Daniela Wojtczaka (Uniwersytet Śląski) pt. Zasada spoteczeństwa obywatelskiego $w$ orzecznictwie Trybunału Konstytucyjnego. Jest to krótka obserwacja na temat zasad społeczeństwa obywatelskiego zarówno w Konstytucji RP z 1997 r., jak i w praktyce stosowanej w orzecznictwie Trybunału Konstytucyjnego. Podstawą zasady społeczeństwa obywatelskiego są bowiem w tymże orzecznictwie: partie polityczne, związki zawodowe, organizacje społeczne i zawodowe rolników, spółdzielnie, ruchy obywatelskie, stowarzyszenia, fundacje i zrzeszenia.

Jarosław Kuczer Uniwersytet Zielonogórski 